\title{
Radioimmunoassay of Cholecystokinin: Production and Evaluation of Antibodies
}

\author{
By J. B. M. J. Jansen and C.B.H.W. Lamers ${ }^{1}$ ) \\ Gastrointestinal Hormone Laboratory, Division of Gastroenterology, St. Radboud Hospital, \\ University of Nijmegen, Nijmegen, The Netherlands
}

(Received January 11, 1982/January 10, 1983)

Summary: In order to produce antibodies for the radioimmunoassay of cholecystokinin the following animals were immunized: 10 rabbits and 3 guinea pigs with cholecystokinin 1-33 coupled to bovine serum albumin, 9 rabbits and 2 guinea pigs with uncoupled cholecystokinin $1-33,5$ rabbits with cholecystokinin 10-20 coupled to bovine serum albumin and 4 rabbits with sulphated cholecystokinin 26-33 coupled to bovine serum albumin. The titer, the binding energy and the specificity of the antibodies were evaluated. Cholecystokinin 1-33, coupled to [ $\left.{ }^{125} \mathrm{I}\right]$ hydroxyphenylpropionic acid-succinimide ester (Bolton-Hunter reagent) to a specific activity of $8.1-14.7 \mathrm{MBq} / \mu \mathrm{g}(219-398 \mu \mathrm{Ci} / \mu \mathrm{g})(\mathrm{n}=8)$, was used as label. After the fourth immunization 5 rabbits immunized with albumin coupled cholecystokinin 1-33 had antibody titers between 1:22500 and 1:80000, while one rabbit immunized with uncoupled cholecystokinin 1-33 had a titer of 1:52000. The affinity constant of these 6 antibodies ranged from $\mathrm{K}=2.0 \times 10^{10}$ to $72.3 \times 10^{10} \mathrm{l} / \mathrm{mol}$. One antibody was specific for all sulphated forms of cholecystokinin, while the other 5 antibodies were specific for the large molecular forms of cholecystokinin. In the guinea pigs immunized with cholecystokinin 1-33 and in the rabbits immunized with cholecystokinin fragments antibody titers were less than 1:500. Concentrations of cholecystokinin in an aqueous-acid extract of human and hog upper small intestine were $48.7 \pm 6.7 \mathrm{pmol} / \mathrm{g}$ and 46.2 $\pm 3.4 \mathrm{pmol} / \mathrm{g}$, when measured with antibody T204 specific for sulphated forms of cholecystokinin, and $49.7 \pm 1.9 \mathrm{pmol} / \mathrm{g}$ and $39.2 \pm 1.6 \mathrm{pmol} / \mathrm{g}$, when measured with antibody 1703 specific for large forms of cholecystokinin. After ingestion of $60 \mathrm{ml}$ corn oil in 6 normal subjects, plasma cholecystokinin increased from $2.7 \pm 0.5 \mathrm{pmol} / /$ to $6.8 \pm 1.7 \mathrm{pmol} / /(\mathrm{p}<0.05)$ when measured with antibody $\mathrm{T} 204$, and from $1.0 \pm 0.3$ $\mathrm{pmol} / 1$ to $5.7 \pm 1.0 \mathrm{pmol} / 1(\mathrm{p}<0.05)$ when measured with antibody 1703 .

In conclusion, immunization of rabbits with cholecystokinin 1-33 resulted in high titer antibodies which could be used in sensitive and specific radioimmunoassays for cholecystokinin.

\section{Radioimmunassay für Cholecystokinin: Gewinnung und Bewertung von Antikörpern}

Zusammenfassung: Zur Gewinnung, von Antikörpern für einen Radioimmunoassay für Cholecystokinin w.urden immunisiert: 10 Kaninchen und 3 Meerschweinchen mit an Rinderserumalbumin gekoppeltem Cholecystokinin 1-33, 9 Kaninchen und 2 Meerschweinchen mit ungekoppeltem Cholecystokinin 1-33, 5 Kaninchen mit an Rinderserumalbumin gekoppeltem Cholecystokinin 10-20 und 4 Kaninchen mit an Rinderserumalbumin gekoppeltẹm, sulfatiertem Cholecystokinin 26-33. Titer, Bindungsenergie und Spezifität der Antikörper wurden bestimmt. Cholecystokinin 1-33, gekoppelt an [ $\left.{ }^{125} \mathrm{I}\right]$ Hydroxyphenylpropionsäuresuccinimid ester (Bolton-Hunter-Reagenz) mit einer spezifischen Aktivität von 8,1-14,7 MBq/ $\mu \mathrm{g}(219-398$ $\mu \mathrm{Ci} / \mu \mathrm{g})(\mathrm{n}=8)$, wurde als Label benutzt. Nach der vierten Immunisierung hatten 5 der mit an Rinderserumalbumin gekoppeltem Cholecystokinin 1-33 immunisierten Kaninchen Antikörpertiter zwischen 1:22500 und 1:80000, während ein mit ungekoppeltem Cholecystokinin 1-33 immunisiertes Kaninchen einen Titer

1) Supported by the Foundation for Medical Research FUNGO (grant No. 13-37-32). 
von 1:52000 aufwies. Die Affinitätskonstante dieser 6 Antikörper lag zwischen $\mathrm{K}=2,0 \times 10^{10}$ und 72,3 $\times$ $10^{10} \mathrm{l} / \mathrm{mol}$. Ein Antikörper war spezifisch für alle sulfatierten Cholecystokinine, während die anderen 5 Antikörper spezifisch für die großmolekularen Cholecystokinine waren. Bei den mit Cholecystokinin 1-33 immunisierten Meerschweinchen und bei den mit Cholecystokinin-Fragmenten immunisierten Kaninchen waren die Antikörpertiter kleiner als 1:500.

Die Cholecystokinin-Konzentrationen in einem wäßrig-sauren Extrakt aus Schleimhaut dés oberen Dünndarms vom Menschen und vom Schwein betrugen 48,7 $\pm 6,7 \mathrm{pmol} / \mathrm{g}$ bżw. 46,2 $\pm 3,4 \mathrm{pmol} / \mathrm{g}$, wenn sie mit Antikörper T204 bestimmt wurden, der für die sulfatierten Cholecystokinine spezifisch ist. Wennn sie mit dem für die großmolekularen Cholecystokinine spezifischen Antikörper 1703 gemessen wurden, lagen sie bei 49,7 $\pm 1,9$ pmol/g bzw. 39,2 $\pm 1,6 \mathrm{pmol} / \mathrm{g}$. Nach Einnahme von $60 \mathrm{ml}$ Maisöl stieg bei 6 gesünden Probanden die Konzentration von Cholecystokinin im Plasma von $2,7 \pm 0,5 \mathrm{pmol} / \mathrm{l}$ auf $6,8 \pm 1,7 \mathrm{pmol} / \mathrm{l}(\mathrm{p}<0.05$; Messung mit Antikörper T204), und von 1,0 $\pm 0,3$ auf 5,7 $\pm 1,0 \mathrm{pmol} / \mathrm{l}$ ( $\mathrm{p}<0.05$; Messung mit Antikörper 1703).

Wir folgern, daß die Immunisierung von Kaninchen mit Cholecystokinin 1-33 zur Bildung von hohen Antikörpertitern führt, die für empfindliche und spezifische Radioimmunoassays für Cholecystokinin benutzt werden können.

\section{Introduction}

Cholecystokinin is one of the classical gut hormones (1). This peptide hormone stimulates gall bladder contraction and secretion of enzymes from the pancreas $(2,3)$. In extracts of gut and brain cholecystokinin was found to be present in several molecular forms (4). Originally cholecystokinin was isolated from acid extracts of hog small intestine as a basic molecule containing 33 amino acid residues (cholecystokinin 1-33) with the chemical structure LysAla-Pro-Ser-Gly-Arg-Val-Ser-Met-Ile-Lys-AsnLeu-Gln-Ser-Leu-Asp-Pro-Ser-His-Arg-Ile-SerAsp-Arg-Asp-Tyr( $\left.\mathrm{SO}_{3}\right)$-Met-Gly-Trp-Met-AspPhe $(4,5)$. A molecular form extended at the $\mathrm{NH}_{2-}$ terminus by 6 amino acid residues, Tyr-Ile-Gln-GlnAla-Arg (cholecystokinin 1-39), was described some years later (6). Recently, it was shown that in neutral extracts of sheep brain a smaller molecular form containing 8 amino acid residues (cholecystokinin 26-33) predominates $(4,7)$.

Even though the first radioimmunoassay of cholecystokinin was reported as early as 1969 (8), only few radioimmunoassays have so far been developed, despite much effort. Several factors contribute to the difficulties in developing a reliable radioimmunoassay for cholecystokinin:

1. difficulties in producing antibodies due to the low immunogenicity (9),

2. an unacceptably high degree of cross-reactivity of $\mathrm{COOH}$-terminal antibodies with gastrin, because both peptides share the same $\mathrm{COOH}$-terminal pentapeptide sequence,
3. suspected species differences in the $\mathrm{NH}_{2}$-terminal sequence of cholecystokinin $1-33$ resulting in antibodies reacting with porcine cholecystokinin but not with cholecystokinin from other species $(10,11)$,

4. availability of only limited amounts of pure cholecystokinin, and

5. difficulties in preparing immuno-reactive cholecystokinin labels. It has been shown that the conventional oxidizing labelling methods, such as the chloramine $T$ methọd and the lactoperoxidase method, result in cholecystokinin labels of poor immunoreactivity, probably due to the deleterious effects of oxidation of the methionine residues in cholecystokinin (12). Recently, the labelling problem has been overcome by using a non-oxidizing labelling method. Using $\left[{ }^{125} \mathrm{I}\right]$ hydroxyphenylpropionic acid-succinimide ester (Bolton-Hunter reagent) Rehfeld was able to produce highly immunoreactive cholecystokinin 1-33 labels, and he suggested that cholecystokinin 1-33 was a good immunogen (12, 13).

In this report we present our experience with the production of antibodies to cholecystokinin in rabbits and guinea pigs. Furthermore, the titer, the binding energy and the specificity of the antibodies were evaluated in radioimmunoassays using BoltonHunter labelled cholecystokinin 1-33. In addition, we have measured cholecystokinin concentrations in extracts of human and hog upper small intestine and in human plasma after ingestion of fat, using radioimmunoassays employing an antibody specific for sulphated forms of cholecystokinin and an antibody specific for large forms of cholecystokinin. 


\section{Materials and Methods}

\section{Peptides}

99\% pure porcine cholecystokinin 1-39 and $30 \%$ and $99 \%$ pure porcine cholecystokinin 1-33 were obtained from Professor Mutt, Karolinska Institute, Stockholm, Sweden; synthetic sulphated and unsulphated cholecystokinin 26-33 from the Squibb Institute, Princetown, N.J., USA; synthetic unsulphated human gastrin 1-17 from Imperial Chemical Industries, Cheshire, England; vasoactive intestinal polypeptide from Peninsula Laboratories, San Carlos, Ca, USA; gastric inhibitory polypeptide from Professor Brown, Vancouver, Canada; sulphated human gastrin 1-17 and sulphated and unsulphated gastrin 1-34 from Professor Grossman, Los Angeles, Ca, USA; secretin synthesized by the Squibb Institute, Princetown, N.J., USA, through the courtesy of Professor Grossman; caerulein from Farmitalia, Milan, Italy; synthetic cholecystokinin 10-20 from UCB, Brussels, Belgium; porcine pancreatic polypeptide, porcine glucagon and monocomponent insulin from Novo Industry, Copenhagen, Denmark; synthetic cholecystokinin 30-33 (tetragastrin) from Sigma, St. Louis, Mo, USÁ.

\section{Other reagents}

$\left[{ }^{125} \mathrm{I}\right]$ hydroxyphenylpropionic acid-succinimide ester (BoltonHunter reagent) was purchased from New England Nuclear, Boston, Ma, USA; Sephadex G 50 SF and SP-Sephadex C 25 from Pharmacia, Uppsala, Sweden; 1-ethyl-3-(3-dimethylaminopropyl) carbodiimide hydrochloride from ICN, Plainview, NY, USA; Freund's complete and incomplete adjuvant from Difco Laboratories, Detroit, Mi, USA; Bordetella pertussis vaccine from RIV, Bilthoven, The Netherlands; human and bovine serum albumin from Behringwerke AG, Marburg/Lahn, West Germany; dextran $\mathrm{T} 70$ and bovine serum albumin (RIA-grade) from Sigma, St. Louis, Mo, USA; trypsin TPCK from Worthington Biochemical Corporation, Freehold, NJ, USA; sodium ethylmercurithiosalicylate from Aldrich-Europe, Beerse, Belgium; double antibody solid phase from Organon, Oss, The Netherlands; all other reagents from E. Merck, Darmstadt, FRG.

\section{Animals}

28 randomly bred rabbits and 5 randomly bred guinea pigs were immunized.

\section{Apparatus}

Automatic $\gamma$-scintillation counter Philips PW 4800, Philips, Eindhoven, The Netherlands; digital diluter dispenser, Hamilton, Bonaduz, Switzerland.

\section{Production of antibodies}

Uncoupled cholecystokinin 1-33: $30 \%$ pure porcine cholecystokinin 1-33 dissolved in $0.05 \mathrm{~mol} / \mathrm{h}$ sodium phosphate buffer $\mathrm{pH}$ 7.5 was used without modification.

\section{Albumin-coupled peptides}

$30 \%$ pure porcine cholecystokinin 1-33, synthetic cholecystokinin $10-20$, and synthetic sulphated cholecystokinin $26-33$ were dissoollved in $0.05 \mathrm{~mol} / \mathrm{A}$ sodium phosphate buffer $\mathrm{pH} 7.5$ and conjugated to bovine serum albumin by reacting with 1-ethyl-3-(3-dimethylaminopropyl) carbodiimide hydrochloride for 2 hours at room temperature and a further 20 hours at $4{ }^{\circ} \mathrm{C}$. The ratio between peptide, bovine serum albumin and 1-ethyl-3-(3-dimethylaminopropyl) carbodiimide hydrochloride on a molar base was 1:0.2:462. The antigen solution was emulsified with equal volumes of Freund's adjuvant for the initial immunizations and with equal volumes of Freund's incomplete adjuvant for booster injections. At the initial immunization $0.5 \mathrm{ml}$ Bordetella pertussis vaccine was administered intramuscularly. Each rabbit was immunized with $2 \mathrm{ml}$ and each guinea pig with $1 \mathrm{ml}$ of the emulsified antigen. The initial injections were given intracutaneously on mul- tiple sites into the back of the animals, while booster injections were given subcutaneously with four weeks intervals on 4 sites. The doses of antigen injected are given in table 1 . Seven days after each booster injection blood was drawn from an ear vein in rabbits and by cardiac puncture in guinea pigs.

Tab. 1. Type (BSA = bovine serum albumin coupled) and amount of antigen used for production of antibodies to cholecystokinin (CCK) in rabbits and guinea pigs.

\begin{tabular}{llllr}
\hline $\begin{array}{l}\text { Animal } \\
\text { species }\end{array}$ & $\begin{array}{l}\text { Num- Antigen } \\
\text { ber } \\
\text { of } \\
\text { ani- } \\
\text { mals }\end{array}$ & $\begin{array}{l}\text { Dose of } \\
\text { antigen } \\
\text { (nmol) }\end{array}$ \\
& & initial $\begin{array}{l}\text { boost- } \\
\text { er }\end{array}$ \\
\hline Rabbit & 10 & $30 \%$ CCK 1-33-BSA & 20 & 10 \\
Rabbit & 9 & $30 \%$ CCK 1-33 & 20 & 10 \\
Rabbit & 5 & CCK 10-20-BSA & 120 & 60 \\
Rabbit & 4 & sulphated CCK 26-33-BSA & 120 & 60 \\
Guinea pig & 3 & $30 \%$ CCK 1-33-BSA & 10 & 5 \\
Guinea pig & 2 & $30 \%$ CCK 1-33 & 10 & 5 \\
\hline
\end{tabular}

\section{Radioiodination}

$37 \mathrm{MBq}(1 \mathrm{mCi})\left[{ }^{125} \mathrm{I}\right]$ hydroxyphenylpropionic acid-succinimide ester (Bolton-Hunter reagent) was dried under a gentle stream of nitrogen according to the instructions of the manufacturer. Five $\mu \mathrm{g} 99 \%$ pure cholecystokinin $1-33$ dissolved in $5 \mu \mathrm{l} 0.05 \mathrm{~mol} / \mathrm{l}$ acetic acid was added to the bottom of the vial. After addition of $15 \mu \mathrm{l} 0.05 \mathrm{~mol} / \mathrm{l}$ sodium borate $\mathrm{pH} 10$, the vial was gently agitated for 30 minutes in an ice bath. To remove excess unreacted ${ }^{125}$ I] hydroxyphenylpropionic acid-succinimide ester, $0.2 \mathrm{~mol} / \mathrm{l}$ glycine in $500 \mu \mathrm{l} 0.05 \mathrm{~mol} / \mathrm{\Lambda}$ sodium borate $\mathrm{pH} 8.5$ was added to the mixture and the vial was agitated for 5 minutes. The reaction mixture was chromatographed at $4^{\circ} \mathrm{C}$ on a Sephadex G $50 \mathrm{SF}$ column, $100 \times 0.9 \mathrm{~cm}$, using $0.5 \mathrm{~mol} / \mathrm{h}$ acetic acid containing $2 \mathrm{~g} /$ gelatine as eluant. Every hour 5 fractions of $1 \mathrm{ml}$ were collected. The elution profile of the radioactivity is shown in figure 1 . Only the second radioactive peak showed immunoreactivity. The fraction with the highest radioactivity in peak II was diluted in the eluting buffer and stored at $-20^{\circ} \mathrm{C}$. This label retained its immunoreactivity for at least 3 months. Label damage was between 2

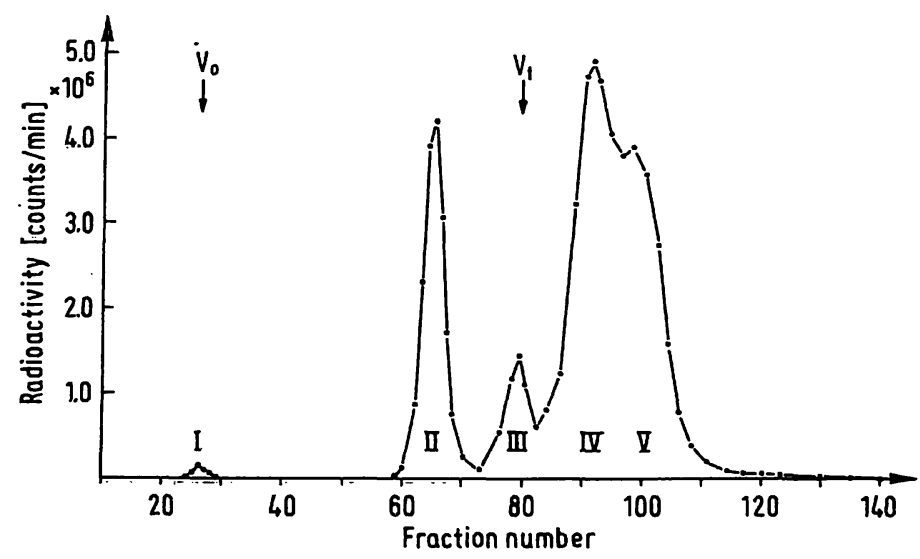

Fig. 1. Elution profile of ${ }^{125}$ I radioactivity after application of reaction mixture of cholecystokinin 1-33 with $\left[{ }^{125} I\right]$ hydroxyphenylpropionic acid-succinimide ester (Bolton-Hunter reagent) to a Sephadex G 50 SF column. Peak II represents labelled cholecystokinin 1-33. For details see text. 
and $7 \%$. The specific activity of the label, determined according to Siadil \& Rehfeld (14), ranged from 8.1 to $14.7 \mathrm{MBq} / \mu \mathrm{g}$ (219 to $398 \mu \mathrm{Ci} / \mu \mathrm{g})(\mathrm{n}=8)$. When the label was rechromatographed on SP-Sephadex C 25 using a 0.05 to $1.0 \mathrm{~mol} / \mathrm{h}$ acetic acid gradient, the radioactivity eluted as a single peak.

\section{Incubation conditions}

Antibody titers were determined as follows. The assays were set up in plastic tubes in an ice bath using $0.02 \mathrm{~mol} / 1$ sodium barbital buffer $\mathrm{pH} 8.4$ containing $0.03 \mathrm{mmol} / \mathrm{h}$ human serum albumin and $0.06 \mathrm{mmol} / \mathrm{h}$ sodium ethylmercurithiosalicylate. The $2.2 \mathrm{ml}$ incubation volume consisted of $1.0 \mathrm{ml}$ of approximately 2000 counts/ min label, $0.2 \mathrm{ml}$ standard solution, and $1.0 \mathrm{ml}$ diluted antiserum. The tubes were incubated for 96 hours at $4{ }^{\circ} \mathrm{C}$. To determine the binding energy and cross-reactivity of the antibodies a pre-equilibrium method was used. $0.2 \mathrm{ml}$ standard solution was incubated with $0.1 \mathrm{ml}$ diluted antiserum for 72 hours at $4^{\circ} \mathrm{C}$. After addition of approximately 2000 counts/min Bolton-Hunter labelled cholecystokinin 1-33 in $0.2 \mathrm{ml}$ buffer, the mixture was incubated for another 48 hours at $4{ }^{\circ} \mathrm{C}$. All dilutions in this pre-equilibrium assay were made in $0.05 \mathrm{~mol} / 1$ sodium phosphate buffer $\mathrm{pH} 7.4$ containing $0.08 \mathrm{mmol} / \mathrm{h}$ human serum albumin and $0.06 \mathrm{mmol} / \mathrm{l}$ sodium ethylmercurithiosalicylate.

\section{Separation procedure}

Antibody-bound radioactivity was separated from free label by addition of a $1.5 \mathrm{ml}$ suspension of $0.05 \mathrm{~mol} / /$ sodium phosphate buffer $\mathrm{pH} 7.4$ containing $25 \mathrm{mg}$ activated charcoal, $2.5 \mathrm{mg}$ dex$\operatorname{tran} \mathrm{T} 70$ and $16 \mathrm{mg}$ bovine serum albumin. The tubes were vortexed and immediately centrifuged $(3000 \mathrm{~g}$ for 10 minutes). In the double-antibody separation technique $1 \mathrm{ml}$ of 1:20 diluted sheep anti-rabbit immunoglobulin was added to the tube and incubated for 4 to 8 hours at $4{ }^{\circ} \mathrm{C}$ before centrifugation. Both the supernatant and the pellet were counted in an automatic $\gamma$-scintillation counter.

\section{Tryptic cleavage}

$230 \mu \mathrm{mol} / 199 \%$ pure cholecystokinin 1-33 was incubated with 5 $\mathrm{g} / 1$ trypsin for 60 minutes at $37^{\circ} \mathrm{C}$. The action of trypsin was terminated by boiling for 10 minutes. The completeness of cleavage of cholecystokinin 1-33 to the COOH-terminal octapeptide (sulphated cholecystokinin 26-33) was assessed by gel filtration of cholecystokinin 1-33 before and after trypsinization on a Sephadex G $50 \mathrm{SF}$ column, $200 \times 1.5 \mathrm{~cm}$, using $0.02 \mathrm{~mol} / \mathrm{/}$ sodium barbital buffer $\mathrm{pH} 8.4$ as eluant at $4^{\circ} \mathrm{C}$. The eluate was measured by radioimmunoassay using a $\mathrm{COOH}$-terminal cholecystokinin antibody and ${ }^{125}$ I labelled non-sulphated cholecystokinin $26-33$ (15).

\section{Tissue extraction}

Pieces of freshly obtained human $(n=3)$ and hog $(n=3)$ upper small intestine were extracted in boiling water $(1 \mathrm{~g} / 10 \mathrm{ml})$ for 10 minutes. After homogenization and centrifugation the supernatant was decanted and the pellet was re-extracted in $0.5 \mathrm{~mol} / \mathrm{l}$ acetic acid $(1 \mathrm{~g} / 10 \mathrm{ml})$ for 10 minutes. After centrifugation the supernatant was added to the supernatant of the aqueous extraction, rapidly frozen, lyophilized, dissolved in $0.05 \mathrm{~mol} / 1$ sodium phosphate buffer and measured by radioimmunoassay.

\section{Measurement of cholecystokinin in plasma}

Blood samples were collected in ice-chilled glass tubes containing $2 \mathrm{~g} /$ ethylenediaminetetraacetate (EDTA). After centrifugation the plasma was frozen at $-20^{\circ} \mathrm{C}$. Cholecystokinin was extracted from plasma by addition of 2 volumes of $960 \mathrm{ml} / 1$ ethanol to 1 volume of plasma. After mixing and centrifugation the supernatant was evaporated to dryness under a stream of nitrogen at $37^{\circ} \mathrm{C}$.
The dried supernatant was reconstituted in assay buffer and 200 $\mu \mathrm{l}$ were incubated with $100 \mu$ ldiluted antiserum for 72 hours at $4^{\circ} \mathrm{C}$. After addition of $200 \mu \mathrm{l}$ labelled cholecystokinin 1-33 containing approximately 2000 counts/min and incubation for another 20 hours at $4^{\circ} \mathrm{C}$, free and antibody-bound peptide were separated and counted in a $\gamma$-scintillation counter. Cholecystokinin 1-33 was used as standard, and antibodies 1703 and T204 as antisera. $0.05 \mathrm{~mol} / 1$ sodium phosphate buffer $\mathrm{pH} 7.4$ containing $0.08 \mathrm{mmol} / \mathrm{A}$ human serum albumin and $0.06 \mathrm{mmol} / \mathrm{h}$ sodium ethylmercurithiosalicylate was used as assay buffer. Recovery of cholecystokinin added to hormone-free plasma was $85.4 \pm 2.0 \%$ (mean $\pm \mathrm{SD} ; \mathrm{n}=11$ ). Separation using plasma-coated charcoal or the double-antibody solid phase technique gave identical results. The detection limit of the assays wâs between 0.5 and 1.0 $\mathrm{pmol} / 1$ plasma. Intra-assay variation ranged from $4.6-8.4 \%$ and inter-assay variation from $11.3=15.4 \%$.

\section{Human studies.}

After an overnight fast 6 normal sübjects ( 4 males and 2 females; mean age 30 years, range $23-38$ years) ingested 60 mil corn oil. Blood samples were obtained at $-5,0,5,10,15,20,30,40,50$, 60,75 and 90 minutes.

\section{Statistics}

Results were expressed as mean \pm SEM, unless otherwise stated. Student's t-test for paired data was used for analysis of the plasma cholecystokinin results.

\section{Results}

The titers of the antibodies after the second, third and fourth immunization are presented in table 2 . Antibodies with titers greater than 1:10000 were not detected after the second immunization, while after the third immunization 3 animals and after the fourth immuniżation 6 animals had produced antibodies with titers of more than $1: 10000$. Of the 10 rabbits immunized with albumin-coupled cholecystokinin $1-33,5$ had antibody titers of more than $1: 10000$ ranging from $1: 22500$ to $1: 80000$. Of the 9 rabbits immunized with uncoupled cholecystokinin 1-33, one produced a high titer antibody, 1:100000 after the third and 1:52000 after the fourth immunization. Immunization with synthetic cholecystokinin fragments (cholecystokinin 10-20 and sulphated cholecystokinin 26-33) did not rêsult in antibodies detectable in radioimmunoassays employing BoltonHunter labelled cholecystokinin 1-33. None of the guinea pigs produced cholecystokinin antibodies with titers of more than 1:500.

In radioimmunoassays using Bolton-Hunter labelled cholecystokinin $1=33$ the binding energy of 6 high titer antibodies after the fourth immunization and of one antibody after the third immunization (1703) were determined. The affinity constants indicating the binding energy between the antibodies and cholecystokinin 1-33 (16) are presented in table 3. 
Four antibodies had very high affinity constants of more than $5 \times 10^{11} \mathrm{l} / \mathrm{mol}$. These high binding energies were reflected in low ID $_{50}$ 's (inhibition dose 50 )

Tab. 2. The dilution of antibodies to cholecystokinin (CCK) in the incubation mixture binding $50 \%$ of $1 \mathrm{fmol}$ BoltonHunter labelled cholecystokinin 1-33.

\begin{tabular}{|c|c|c|c|}
\hline \multirow[t]{2}{*}{ Animal number } & \multicolumn{3}{|c|}{$\begin{array}{l}\text { Reciprocal of antibody dilution } \\
\text { after }\end{array}$} \\
\hline & $\begin{array}{l}\text { immuni- } \\
\text { zation II }\end{array}$ & $\begin{array}{l}\text { immuni- } \\
\text { zation III }\end{array}$ & $\begin{array}{l}\text { immuni- } \\
\text { zation IV }\end{array}$ \\
\hline \multicolumn{4}{|l|}{ Rabbit } \\
\hline $\begin{array}{l}30 \% \text { CCK } 1-33-B \\
11 \\
12 \\
13 \\
14 \\
\text { T1 } \\
\text { T2 } \\
\text { T3 through T6 }\end{array}$ & $\begin{array}{l}1000 \\
5000 \\
2000 \\
2000 \\
<500 \\
\text { n.t. } \\
<500\end{array}$ & $\begin{array}{r}1800 \\
6000 \\
10000 \\
60000 \\
<500 \\
3700 \\
<500\end{array}$ & $\begin{array}{r}2750 \\
27000 \\
75000 \\
50000 \\
22500 \\
80000 \\
<500\end{array}$ \\
\hline $\begin{array}{l}30 \% \text { CCK } 1-33 \\
15 \\
16 \\
17 \\
18 \\
\text { T7 } \\
\text { T8 through T11 }\end{array}$ & $\begin{array}{l}<500 \\
<500 \\
2000 \\
<500 \\
<500 \\
<500\end{array}$ & $\begin{array}{r}1700 \\
2400 \\
100000 \\
1800 \\
<500 \\
<500\end{array}$ & $\begin{array}{r}<500 \\
1500 \\
52000 \\
2500 \\
2600 \\
<500\end{array}$ \\
\hline $\begin{array}{l}\text { CCK 10-20-BSA } \\
1 \text { through } 5\end{array}$ & $<500$ & $<500$ & $<500$ \\
\hline \multicolumn{4}{|c|}{ Sulphated CCK 26-33-BSA } \\
\hline \multicolumn{4}{|l|}{ Guinea pig } \\
\hline $\begin{array}{c}30 \% \text { CCK } 1-33-B \\
\text { G1 through G3 }\end{array}$ & $<500$ & $<500$ & $<500$ \\
\hline $\begin{array}{l}30 \% \text { CCK } 1-33 \\
\text { G4 and G5 }\end{array}$ & $<500$ & $<500$ & $<500$ \\
\hline
\end{tabular}

n.t. $=$ not tested

$\mathrm{BSA}=$ bovine serum albumin coupled between 2.8 and $5.0 \mathrm{pmol} / \mathrm{l}$ in the radioimmunoassays. With these sensitive radioimmunoassays for cholecystokinin 1-33, very low detection limits ranging from 0.5 to $3 \mathrm{pmol} / 1$ sample were obtained.

All antibodies cross-reacted with cholecystokinin 1-39 (table 3). Five antibodies $(1204,1304,1404$, T104 and 1703/1704) did not cross-react with either synthetic cholecystokinin fragments or cholecystokinin fragments produced by trypsinization (table 3 ). Furthermore, these antibodies did not show any binding to sulphated or non-sulphated gastrins, to COOH-terminal tetragastrin (cholecystokinin $30-33$ ), to caerulein or to structurally unrelated peptides such as insulin, glucagon, pancreatic polypeptide, gastric inhibitory polypeptide, vasoactive intestinal polypeptide or secretin. Antibody T 204 bound to cholecystokinin 33, cholecystokinin 39, sulphated cholecystokinin $26-33$, caerulein and to trypsinized cholecystokinin 33 (table 3 ). Binding to sulphated gastrin 1-17 and sulphated gastrin 1-34 was low, while binding to non-sulphated forms of cholecystokinin or gastrin and to unrelated peptides was absent. All 6 antibodies did not only bind to porcine cholecystokinin, but also to cholecystokinin in human tissue extracts.

Standard curves for both types of antibodies are shown in figures 2 and 3.

Concentrations of cholecystokinin in an aqueous acid extract of human $(n=3)$ and hog $(n=3)$ upper small intestine were $48.7 \pm 6.7 \mathrm{pmol} / \mathrm{g}$ and $46.2 \pm$ $3.4 \mathrm{pmol} / \mathrm{g}$, when measured with antibody $\mathrm{T} 204$, and $49.7 \pm 1.9 \mathrm{pmol} / \mathrm{g}$ and $39.2 \pm 1.6 \mathrm{pmol} / \mathrm{g}$, when measured with antibody 1703.

Tab. 3. Binding energy, iṇhịition dose 50 and cross-reactivity of high titer cholecystokinin (CCK) antibodies***.

\begin{tabular}{|c|c|c|c|c|c|c|c|c|c|c|c|c|}
\hline $\begin{array}{l}\text { Añti- } \\
\text { bodjy } \\
\text { nụmber }\end{array}$ & $\mathbf{K}^{*}$ & $\mathrm{ID}_{50}{ }^{* *}$ & $\begin{array}{c}\text { CCK } \\
1-33\end{array}$ & $\begin{array}{l}\text { CCK } \\
1-39\end{array}$ & $\begin{array}{l}\text { CCK } \\
10-20\end{array}$ & Caerulein & $\begin{array}{l}\text { Sul- } \\
\text { phated } \\
\text { CCK } \\
26-33\end{array}$ & $\begin{array}{l}\text { Non-sul- } \\
\text { phated } \\
\text { CCK } \\
26-33\end{array}$ & $\begin{array}{l}\text { Trypsin- } \\
\text { ized } \\
\text { CCK } \\
1-33\end{array}$ & $\begin{array}{l}\text { CCK } \\
30-33\end{array}$ & $\begin{array}{l}\text { Sul- } \\
\text { phated } \\
\text { gastrin } \\
1-17\end{array}$ & $\begin{array}{l}\text { Sul- } \\
\text { phated } \\
\text { gastrin } \\
1-34\end{array}$ \\
\hline$\ddot{n}$ & & & & & & & & & & & & \\
\hline $\begin{array}{l}1204 \\
1304\end{array}$ & $\begin{array}{r}2.0 \\
72.3\end{array}$ & $\begin{array}{r}26.0 \\
4.5\end{array}$ & $\begin{array}{l}1.0 \\
1.0\end{array}$ & $\begin{array}{l}0.80 \\
0.49\end{array}$ & $\begin{array}{l}<0.001 \\
<0.001\end{array}$ & $\begin{array}{l}<0.001 \\
<0.001\end{array}$ & $\begin{array}{l}<0.001 \\
<0.001\end{array}$ & $\begin{array}{l}<0.001 \\
<0.001\end{array}$ & $\begin{array}{l}<0.001 \\
<0.001\end{array}$ & $\begin{array}{l}<0.001 \\
<0.001\end{array}$ & $\begin{array}{l}<0.001 \\
<0.001\end{array}$ & $\begin{array}{l}<0.001 \\
<0.001\end{array}$ \\
\hline 1404 & 2.8 & 24.0 & 1.0 & 0.80 & $<0.001$ & $<0.001$ & $<0.001$ & $<0.001$ & $<0.001$ & $<0.001$ & $<0.001$ & $<0.001$ \\
\hline T104 & 55.4 & 5.0 & 1.0 & 0.50 & $<0.001$ & $<0: 001$ & $<0.001$ & $<0.001$ & $<0.001$ & $<0.001$ & $<0.001$ & $<0.001$ \\
\hline T204 & 52.2 & 3.3 & 1.0 & 1.12 & $<0.001$ & 0.20 & 0.93 & $<0.001$ & 0.88 & $<0.001$ & 0.016 & 0.018 \\
\hline 17.03 & 59.4 & 2.8 & 1.0 & 0.89 & $<0.001$ & $<0.001$ & $<0.001$ & $<0.001$ & $<0.001$ & $<0.001$ & $<0.001$ & $<0.001$ \\
\hline 1704 & 31.6 & 5.1 & 1.0 & 0.88 & $<0.001$ & $<0.001$ & $<0.001$ & $<0.001$ & $<0.001$ & $<0.001$ & $<0.001$ & $<0.001$ \\
\hline
\end{tabular}

* Affinity constant $\mathrm{K}\left(\times 10^{10} \mathrm{l} / \mathrm{mol}\right)$

** Inhibition dose 50: dose of cholecystokinin 1-33 which reduces binding between label and antibody by 50\% (pmol/l)

*** None of the antibodies showed cross-reactivity with non-sulphated gastrin 17, non-sulphated gastrin 34 or unrelated regulatory peptides 


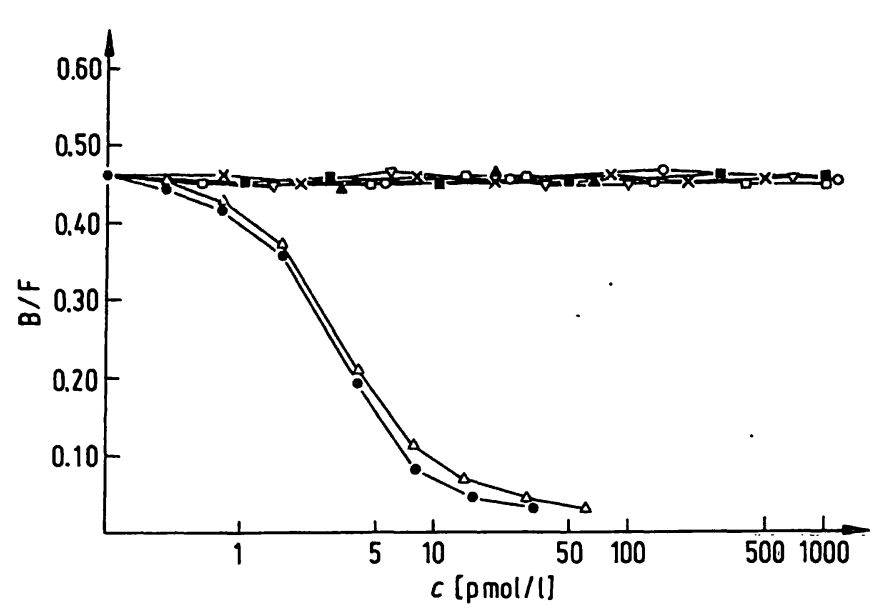

Fig. 2. Standard curves of antibody 1703 using Bolton-Hunter labelled cholecystokinin $1-33$. The antibody binds to cholecystokinin 1-33 $(0)$ and cholecystokinin 1-39 $(\Delta)$, but not to sulphated gastrin $(\Delta)$, unsulphated gastrin $(\nabla)$, sulphated cholecystokinin $26-33(x)$, unsulphated cholecystokinin 26-33 (O), trypsinized cholecystokinin 1-33

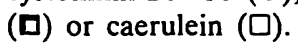

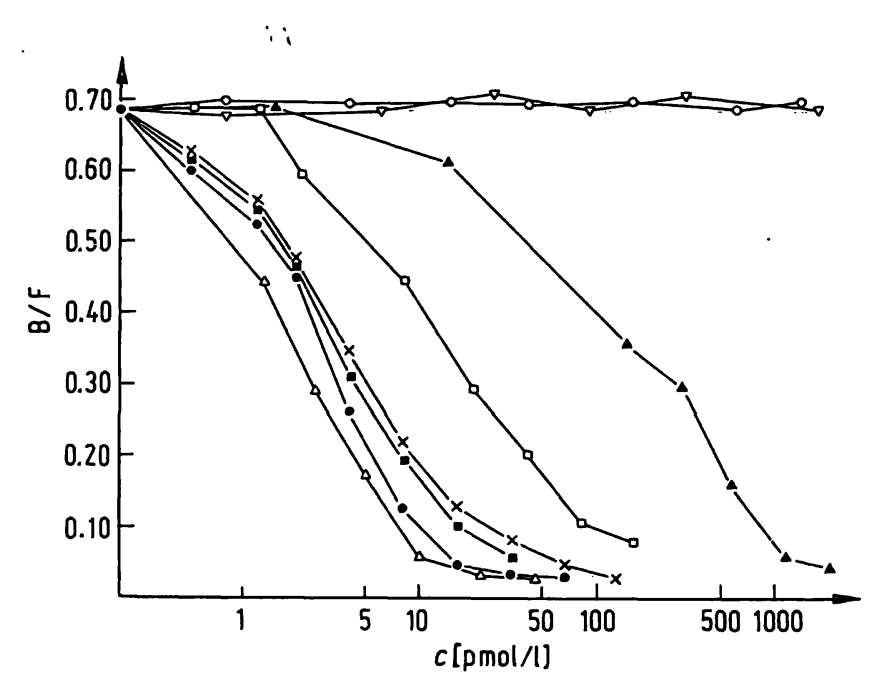

Fig. 3. Standard curves of antibody T204 using Bolton-Hunter labelled cholecystokinin 1-33. The antibody binds to cholecystokinin-gastrin peptides containing the sulphated tyrosine region: cholecystokinin 1-39 $(\triangle)$, cholecystokinin 1-33(0), trypsinized cholecystokinin 1-33( $(\mathbf{a})$, sulphated cholecystokinin 26-33 (x), caerulein $(\square)$ and sulphated gastrin ( $\Delta)$. Binding to cholecystokinin-gastrin peptides lacking the sulphated tyrosine region is absent: unsulphated cholecystokinin 26-33(O), and unsulphated gastrin $(\nabla)$.

Basal plasma cholecystokinin concentrations were very low, $2.7 \pm 0.5 \mathrm{pmol} / \mathrm{h}$ as measured with antibody $\mathrm{T} 204$, and $1.0 \pm 0.3 \mathrm{pmol} / \mathrm{l}$ as measured with antibody 1703. Ingestion of corn oil induced significant increases in plasma cholecystokinin $(p<0.05)$. The peak plasma cholecystokinin concentrations were found 20 minutes after ingestion of the corn oil. The increases in plasma cholecystokinin were similar for both antibodies (fig. 4).

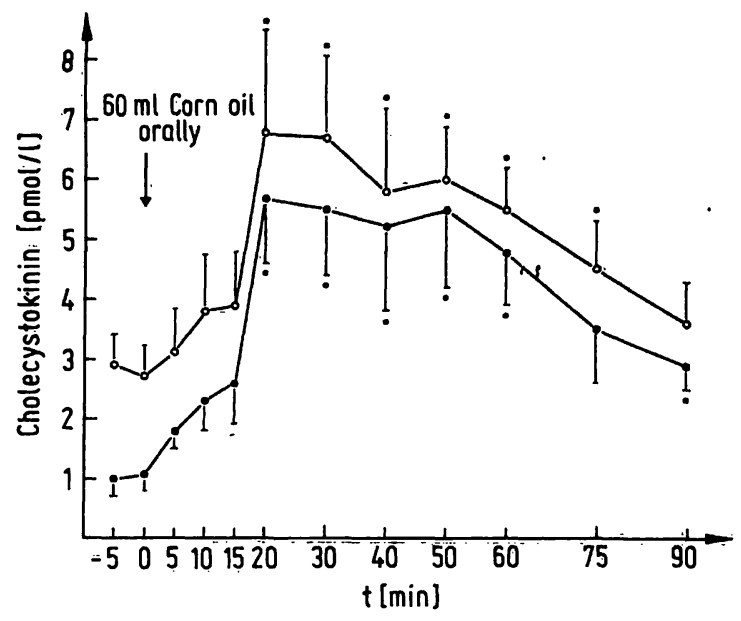

Fig. 4. The effect of ingestion of $60 \mathrm{ml}$ corn oil on plasma cholecystokinin concentrations in 6 normal subjects. Open circles indicate antibody T204 and filled circles antibody 1703. Asterisks indicate significant differences from basal value $(p<0.05)$.

\section{Discussion}

This study shows that cholecystokinin $1-33$ is an excellent immunogen when Bolton=Hunter labelled cholecystokinin $1-33$ is employed as the radioactive peptide in radioimmunoassays. Immunization of rabbits with albumin-coupled cholecystokinin $1-33$ produced high titer antibodies in 5 of 10 animals, while immunization of 9 rabbits with uncoupled cholecystokinin 1-33 produced high titer antibodies in one animal. Four of these antibodies had high binding energies with affinity constants of more than $5 \times 10^{11} \mathrm{l} / \mathrm{mol}$. No antibodies were obtained in guinea pigs immunized with uncoupled or albumincoupled cholecystokinin $1-33$ or in rabbits immunized with albumin-coupled cholecystokinin fragments. Therefore, immunization of rabbits with albumin-coupled cholecystokinin $1 \div 33$ seems to be the most suitable method to produce antibodies for the radioimmunoassay of cholecystokinin. In contrast to a previous report (9); our results confirm Rehfeld's finding that cholecystokinin 1-33 has good immunogenic properties (12). It has been claimed by Rehfeld that cholecystokinin $1-33$ is a good immunogen provided cholecystokinin is not exposed to oxidation during the labelling procedure (12). However, high titer cholecystokinin antibodies have been described in radioimmunoassays using cholecystokinin 1-39 or nonsulphated cholecystokinin $26-33$ labelled with ${ }^{125} \mathrm{I}$ by the chloramine $\overline{\mathrm{T}}$ method $(15,17,18)$. On the other hand, it seems to be extremely difficult to raise high titer antibodies against cholecystokinin 1-33 when an oxidizing labelling method is used. Thompson's group has produced an antibody against cholecystokinin 1-33 
which binds 25 to $35 \%$ of cholecystokinin 1-39, labelled with ${ }^{125} \mathrm{I}$ by the chloramine $\mathrm{T}$ method, at a final dilution of $1: 100000$ (17). In most radioimmunoassays using cholecystokinin $1-33$ or cholecystokinin $1-39$, labelled by the chloramine $\mathrm{T}$ method, the titers of the antibodies are extremely low $(8,10$, $19,20,21)$. From the present study it cannot be concluded whether the excellent immunogenicity of cholecystokinin $1-33$ in our hands is attributable to the immunization schedule employed or to the use of a non-oxidizing labelling method. Using BoltonHunter labelled cholecystokinin 1-33, Rehfeld reported cholecystokinin antibodies with a titer between $1: 10000$ and $1: 30000$ in 3 of 10 rabbits immunized with albumin-coupled cholecystokinin 1-33 (12). However, none of these antibodies had affinity constants above $5 \times 10^{11} \mathrm{l} / \mathrm{mol}$. Byrnes et al. (22) immunized 16 rabbits with albumin-coupled cholecystokinin 1-33 and only one of the animals produced an antibody with a titer of $1: 10000$. When Bolton-Hunter labelled cholecystokinin 1-33 was used in the assay the affinity constant was $5.5 \times 10^{11}$ $1 / \mathrm{mol}$ (22). Rehfeld suggested that cholecystokinin $1-33$ is particularly immunogenic in guinea pigs (12). Twelve of 30 animals produced antibodies with titers between 1:10000 and 1:50000. Three of these antibodies had affinity constants of more than $5 \times$ $10^{11} \mathrm{l} / \mathrm{mol}$. While Rehfeld (12) and Byrnes et al. (22) did not find antibody titers higher than 50000 , we found this level of titers in 4 rabbits. Some authors advocate an immunization schedule in which crude cholecystokinin $1-33$ is used for the initial immunizations followed by $99 \%$ pure cholecystokinin 1-33 for the final immunization (17). In our study excellent antibodies were obtained after immunization with $30 \%$ pure cholecystokinin $1-33.99 \%$ pure cholecystokinin $1-33$ is difficult to obtain and our data do not support the need for highly purified cholecystokinin $1-33$ as immunogen.

The high binding energy of 4 antibodies ( $K>5 \times$ $10^{11} \mathrm{l} / \mathrm{mol}$ ) in the present study was reflected in the high sensitivity of the radioimmunoassays. The dose of cholecystokinin 1-33 at which the binding between label and antibody was inhibited by $50 \%$ (ID 50 ) ranged from 2.8 to $5.0 \mathrm{pmol} / \mathrm{l}$. The detection limit of these assays was between 0.5 and $3 \mathrm{pmol} / \mathrm{l}$ sample. These assays were extremely sensitive and they were able to measure the very low concentrations of cholecystokinin present in the circulation (fig. 4).
Five antibodies bound to cholecystokinin 1-33 and cholecystokinin $1-39$, but not to synthetic cholecystokinin fragments (sulphated and non-sulphated cholecystokinin 26-33, cholecystokinin 30-33, cholecystokinin 10-20) or cholecystokinin fragments prepared by trypsinization of cholecystokinin 1-33 (cholecystokinin 1-6, cholecystokinin 7-11, cholecystokinin $12-21$, cholecystokinin $22-25$, sulphated cholecystokinin 26-33). Go et al. (10) and Straus \& Yalow (11) produced antibodies to cholecystokinin 1-33 which reacted only with porcine cholecystokinin, but not with cholecystokinin from other species. They suggested that there might be species differences in the structure of cholecystokinin 1-33 at the $\mathrm{NH}_{2}$-terminus. Our antibodies not only bound to porcine cholecystokinin but also to human cholecystokinin. Since the antibodies do not cross-react with gastrin or with structurally unrelated peptides, these antibodies are extremely suitable for quantifying large forms of cholecystokinin in blood and tissue. One antibody (T204) seems to be directed to the sulphated tyrosine region of the molecule. It binds to large cholecystokinin and cholecystokinin fragments containing the sulphated tyrosine region (cholecystokinin 1-39, cholecystokinin 1-33, caerulein, sulphated cholecystokinin $26-33$, trypsinized cholecystokinin 33) but not to unsulphated cholecystokinin fragments (non-sulphated cholecystokinin 26-33, cholecystokinin 10-20, cholecystokinin $30-33)$. Since the binding to sulphated gastrin $1-17$ and sulphated gastrin $1-34$ is low and the binding to non-sulphated gastrin 1-17 and gastrin 1-34 and structurally unrelated peptides is absent, this antibody is suitable for quantifying the sulphated forms of cholecystokinin in blood and tissue. Since only sulphated molecular forms of cholecystokinin possess biological activity, this assay will quantify only the biological active forms of cholecystokinin.

In conclusion, immunization of rabbits with cholecystokinin 1-33 resulted in antibodies which can be used in sensitive and specific radioimmunoassays for cholecystokinin.

\section{Acknowledgements}

The authors are endebted to Mr. J. Koedam and Dr. W. van der Gulden, Central Animal Laboratory, and to Mr. H. J. Jansen for their assistance in immunizing the animals. 


\section{References}

1. Rayford, P. L., Miller, T. A. \& Thompson, J. C. (1976) N. Engl. J. Med. 294, 1093-1101.

2. Ivy, A. C. \& Oldberg, E. (1928) Am. J. Physiol. 86, 599-613.

3. Harper, A. A. \& Raper, M. S. (1943) J. Physiol. (London) $102,115-125$.

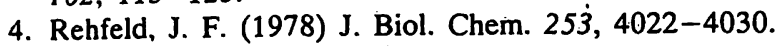

5. Mutt, V. \& Jorpes, J. E. (1968) Eur. J. Biochem. 6, $156-162$.

6. Mutt, V. (1976) Clin. Endocrinol. 5, 175S-183S.

7. Dockray, G. J. (1977) Nature 270, 359-361.

8. Young, J. D., Lazarus, L., Chisholm, D. J. \& Atkinson, F. F. V. (1969) J. Nucl. Med. 10, 743-745.

9. Bloom, S. R. (1974) Br. Med. Bull. 30, 62-67.

10. Go, V. L. W., Ryan, R. J. \& Summerskill, W. H. J. (1971) J. Lab. Clin. Med. 77, 684-689.

11. Straus, E. \& Yalow, R. S. (1978) Proc. Natl. Acad. Sci. (USA) $75,486-489$

12. Rehfeld, J. F. (1978) J. Biol. Chem. 253, 4016-4021.
13. Bolton, A. E. \& Hunter, W. M. (1973) Biochem. J. 133, 529-5.39.

14. Stadil, F. \& Rehfeld, J. F. (1972) Scañd, J. Clin. Lab. Invest. 30, 361-368.

15. Lamers, C. B., Morley, J. E., P.oitras, P., Sharp, B., Carlson, H. E., Hershman, J. M. \& Walsh, J. H. (1980) Am̄. J. Physiol. 239, E232-E235.

16. Scatchard, G. (1949) Anni. N.Y. Acäd. Sci. 51, 660-672.

17. Miyata, M., Rayford, P. L. \& Thompson, J. C. (1980) Surgery $87,209-215$.

18. Dockray, G. J. (1980) Brain Res. 188, 155-165.

19. Reeder, D. D., Becker, H. D., Smith, N. J., Rayford, P. L. \& Thompson, J. C. (1973) Ann. Surg. 178, 304-310.

20. Harvey, R. F., Dowsett, L., Hartog, M. \& Read, A. E. (1974) Gut 15, 690-699.

21. Schlegel, W., Raptis, S., Grube; D. \& Pfeiffer, E. F. (1977) Clin. Chim. Acta 80, 305-316.

22. Byrnes, D. J., Henderson, L., Borody, T. \& Rehfeld, J. F. (1981) Clin. Chim. Acta $111,81=89$.

Dr. C. B. H. W. Lamers

Division of Gastroenterology

St. Radboud Hospital

University of Nijmegen

NL-6500 HB Nijmegen

The Netherlands 